\title{
KESENIAN PANTING DI KALIMANTAN SELATAN
}

\author{
M. Shalahuddin Hijratullah \\ Email: 2010128210021@ mhs.ulm.ac.id \\ Program Studi Pendidikan IPS Fakultas Keguruan dan Ilmu Pendidikan \\ Universitas Lambung Mangkurat \\ Banjarmasin
}

\begin{abstract}
Abstrak
Pada umumnya kesenian musik panting kesenian yang berasal dari kalimantan selatan. Didalam artikel ini berisikan sejarah dari kesenian panting yang berasal dari daerah barikin. Yang dipelopori oleh yang bernama Abdul Wahab Syarbaini. Kemudian berisikan fungsi dari musik panting, kemudian apa-apa saja nilai-nilai sosial yang dapat diambil agar kita sebagai masyarakat terutama generasi jaman sekarang agar dapat mengetahui dan mempertahankan kesenian panting ini.
\end{abstract}

\section{PENDAHULUAN}

Menurut KBBI, seni memiliki banyak arti. Artinya pertama, pengetahuan profesional yang membuat pekerjaan berkualitas. Kedua, karya yang diciptakan dengan keterampilan luar biasa, seperti seni tari, seni lukis, dan seni pahat. Ketiga, rasionalitas menciptakan kemampuan menciptakan nilai yang tinggi (luar biasa). Kebudayaan merupakan aset penting negara sebagai alat sosial dan simbol kerja daerah.

Musik panting adalah kesenian Kalimantan Selatan yang merupakan hasil karya ini dan telah berkembang di masyarakat suku Banjar. Kesenian ini biasanya dibawakan oleh masyarakat di pedesaan dan perkotaan. Musik panting juga diajak ke daerah lain, seperti Kalimantan Tengah, Kalimantan Timur, dan Jawa. Musik sesak dilakukan tidak hanya dalam kegiatan yang diadakan di masyarakat, tetapi juga dalam kegiatan formal yang melibatkan pejabat.

Dalam hal itu saya ingin mengetahui lebih dalam mengenai kesenian musik panting yaitu sejarahnya, manfaat, fungsinya, dan nilai sosial yang terkandung didalam kesenian panting. 


\section{SEJARAH MUSIK PANTING}

Istilah panting memiliki dua arti: Pertama, panting adalah nama alat musik kordofon yang berasal dari alat musik kecapi di daerah Dayak, yang kemudian dipengaruhi oleh gambus melayu. Bentuk alat musik panting ini sangat mirip dengan gambus yang populer di dunia Melayu. Kata panting berasal dari keahlian memainkan alat musiknya yaitu dipetik. Alat panting hanya digunakan oleh masyarakat banjar hulu, sedangkan masyarakat banjar pesisir menggunakan alat gambus melayu. Kedua, panting adalah nama dari sebuah ensambel musik, dengan alat utama sebagai alat musik utama, dan tangga nada yang digunakan mendekati atau sangat mirip dengan tangga nada diatonis.

Pada tahun 1973 Abdul Wahab Syarbaini menjadi salah satu seorang seniman daerah di Desa Barikin. "Desa Barikin merupakan tempat pelestarian dan pengembangan musik banjar tradisional. Seperti kita ketahui bersama, Desa Barikin terletak di lingkungan Haruyan Kabupaten Hulu Sungai Tengah. Ia diiringi oleh kesenian tradisional Bajapin dan alat musik yang sangat sederhana, diantaranya 1 buah panting, 1 babun dan 1 gong.

Pada tahun 1977, musik panting membawakan lagu pahuluan banjar melayu, lagulagu ini dimainkan dengan ritme yang lambat di siang hari, dan lirik lagunya memberikan nasihat. Pada tahun 1978, ia mengubah lagu yang secara khusus dimainkan dengan musik panting. Pada tahun 1979, beberapa alat musik lain ditambahkan ke dalam seni musik panting. Oleh karena itu, alat musik dalam seni musik asma ini antara lain adalah 3 panting, 1 talinting, 2 gong, 1 set giring-giring, 1 seruling, 1 biola.

Kesenian panting ini mampu berdiri sendiri yang menjadi salah satu seni

pertunjukan, pada umumnya musik panting dipertunjukan sebagai hiburan dengan membawakan lagu-lagu tradisonal dari daerah kalimantan selatan. Pada fungsinya musik panting awalnya disebut sebagai musik pengiring kesenian bajapin, dimana panting memiliki fungsi hanya sebagai bagian pelengkap dalam kesenian bajapin.

\section{NILAI-NILAI SOSIAL MUSIK PANTING}

Banyaknya nilai luhur dalam kehidupan tradisional menjadi kekayaan budaya yang harus dipertahankan dan dijaga. Kesenian termasuk seni yang merupakan refleksi 
kehidupan (norma-norma dan nilai-nilai) misalnya dalam penyajian panting yang bisa mengubah suasana emosional kehidupan menjadi lebih memiliki rasa yang berbeda dengan modern. Pesan-pesan yang bisa didapatkan dari musik panting adalah agar anggota masyarakat tidak dapat melakukan kejahatan yang mendatangkan musibah, agar masyarakat dapat menghormati orang yang lebih tua.

Nilai yang terkandung dalam musik panting adalah sebuah cerita atau syair yang menyajikan tentang sejarah kehidupan, contoh teladan yang baik, kritik sosial atau sindiran yang bersifat membangun, demokratis, dan nilai-nilai budaya masyarakat Banjar. Kegiatan bermusik, tidak hanya dapat dipergunakan untuk menyalurkan bakat dan hobi para seniman music, musik juga dapat dijadikan sebagai salah satu cara untuk memperoleh penghasilan. Dan juga ada sebagian orang yang pekerjaannya dalam bidang seni musik, baik sebagai pencipta lagu atau pemusik.

\section{SIMPULAN}

Kesenian panting merupakan sebuah pertunjukkan yang sering ditunjukkan di wilayah Kalimantan selatan. Panting memiliki arti yaitu nama alat musik kordofon yang berasal dari alat musik kecapi di daerah Dayak, yang kemudian dipengaruhi oleh gambus melayu. Alat musik panting diciptakan oleh seorang bernama Abdul Wahab Syarbaini yang merupakan salah satu seniman dari daerah barikin. Alat musik panting ini awalnya berfungsi sebagai alat music pengiring pada kesenian bajapin. Nilai-nilai sosial yang terkandung didalam kesenian musik panting ini adalah untuk membangun solidaritas dan juga menyajikan kisah kehidupan, maupun memberikan pencerahan kepada masyarakat agar tidak melakukan kejahatan dan juga untuk menghormati orang yang lebih tua.

\section{REFERENSI}

Abbas, E. W. (2015). Pendidikan IPS Berbasis Kearifan Lokal. WAHANA Jaya Abadi.

Anderiani, L. (2016). Musik Panting di Desa Barikin Kalimantan Selatan: Kemunculan, Keberadaan dan Perubahannya. Resital: Jurnal Seni Pertunjukan (Journal of Performing Arts), 17(3), 140-157. 
Felix, J. (2012). Pengertian seni sebagai pengantar kuliah Sejarah Seni

Rupa. Humaniora, 3(2), 614-621.

Suryana, R. NILAI-NILAI SOSIAL DALAM PENYAJIAN MUSIK PANTING DI BANJARMASIN. Jurnal Socius, 4(2). 